\title{
IMPLEMENTASI KELAS IBU HAMIL SEBAGAI UPAYA PENURUNAN STUNTING DI WILAYAH KERJA PUSKESMAS AMPAH II KABUPATEN BARITO TIMUR
}

\author{
Oktaviani*1, Heti Ira Ayue $^{1}$, Riny Natalina ${ }^{1}$ \\ ${ }_{1}^{1}$ Jurusan Kebidanan Poltekkes Kemenkes Palangka Raya, Indonesia \\ *e-mail: oktaviani@ @oltekkes-palangkaraya.ac.id ${ }^{1}$
}

\begin{abstract}
Stunting is known as one of chronic nutritional deficient occurred during antenatal and visible at two year of age. These conditions lead to moratlity rate on post-partum and childhood. According to Riset Kesehatan Dasar 2013 data, national stunting prevalence reaching 37,2\%, compared with 2007 and 2010. Central Kalimantan, at the end of of 2017, stunting data reach $39 \%$ among toddlers, whereas Barito Timur have highest prevalence, 58,84\%. Prevention and monitoring during pregnancy is one of the most effective to gain women on pregnant quality life. Indonesian government has launched program so-called antenatal class. Community outreach are conducted to cope with Indonesian government program. It addressed to eight pregnant women within Puskesmas Ampah II area. During the event, pregnant women have gained knowledge related to stunting. Moreover, they are able to have interaction as well as discuss issues related with pregnancy. Midwives, whom work at the Puskesmas are also able to engaged with those pregnant women. As conclude remark, antenatal class is a good non-formal way to share knowledge related to stunting.
\end{abstract}

Keywords: Antenal Class, Women Pregnancy, Stunting

\begin{abstract}
ABSTRAK
Stunting merupakan salah masalah kurang gizi kronis yang terjadi pada mulai janin masih dalam kandungan dan baru nampak pada usia berusia dua tahun. Kekurangan gizi pada usia dini meningkatkan angka kematian bayi dan anak. Riset Kesehatan Dasar 2013 mencatat prevalensi stunting nasional mencapai 37,2 persen, meningkat dari tahun 2010 (35,6\%) dan 2007 (36,8\%). Di Provinsi Kalimantan Tengah jumlah anak stunting sampai akhir 2017 mencapai 39\% dari total anak balita. Kabupaten Barito Timur merupakan salah satu Kabupaten yang angka kejadian stunting tinggi yaitu sebesar $54,84 \%$. Persiapan dan pengawasan selama masa kehamilan merupakan salah satu upaya untuk meningkatkan kualitas ibu hamil. Pemerintah Indonesia dalam upaya meningkatkan kesehatan ibu dan anak melalui program kelas ibu hamil. Kegiatan pengabdian masyarakat ini dengan metode pendidikan kesehatan melalui kelas ibu hamil. Sasaran kegiatan ini adalah 8 orang ibu hamil yang ada di wilayah kerja Puskesmas Ampah II. Hasil kegiatan ini diperoleh ibu hamil terdapat peningkatan pengetahuan tentang stunting dan ibu hamil dapat melakukan interaksi dan diskusi mengenai masalah maupun kebutuhan selama masa kehamilan. Selain itu, bidan di Puskesmas juga semakin mengenal lebih dekat ibu hamil.
\end{abstract}

50 Edukasi Masyarakat Sehat Sejahtera (EMaSS) : Jurnal Pengabdian kepada Masyarakat Volume 2 No.1 Tahun 2020 
Implementasi Kelas ibu hamil sebagai salah satu wahana yang dapat digunakan dalam berbagi informasi pengetahuan dan wawasan mengenai stunting.

Kata kunci: Kelas Ibu, Ibu Hamil, Stunting

\section{PENDAHULUAN}

Stunting adalah masalah kurang gizi kronis yang disebabkan oleh asupan gizi yang kurang dalam waktu cukup lama akibat pemberian makanan yang tidak sesuai dengan kebutuhan gizi. Stunting terjadi mulai janin masih dalam kandungan dan baru nampak saat anak berusia dua tahun. Kekurangan gizi pada usia dini meningkatkan angka kematian bayi dan anak, menyebabkan penderitanya mudah sakit dan memiliki postur tubuh tak maksimal saat dewasa. Kemampuan kognitif para penderita juga berkurang, sehingga mengakibatkan kerugian ekonomi jangka panjang bagi Indonesia (KDPDTT, 2017). Riset Kesehatan Dasar 2013 mencatat prevalensi stunting nasional mencapai 37,2 persen, meningkat dari tahun 2010 (35,6\%) dan 2007 $(36,8 \%)$. Artinya, pertumbuhan tak maksimal diderita oleh sekitar 8,9 juta anak Indonesia, atau satu dari tiga anak Indonesia. Prevalensi stunting di Indonesia lebih tinggi daripada negara-negara lain di Asia Tenggara, seperti Myanmar (35\%), Vietnam (23\%), dan Thailand (16\%) (Kemenkes RI, 2013).

Faktor gizi ibu sebelum dan selama kehamilan merupakan penyebab tidak langsung yang memberikan kontribusi terhadap pertumbuhan dan perkembangan janin. Ibu hamil dengan gizi kurang akan menyebabkan janin mengalami Intrauterine Growth Retardation (IUGR), sehingga bayi akan lahir dengan kurang gizi, dan mengalami gangguan pertumbuhan dan perkembangan serta mudah untuk terkena penyakit degeneratif saat dewasa kelak (fetal origin desease). Salah satu faktor gizi yang banyak dialami selama ibu hamil adalah mengalami anemia pada masa kehamilan (KKBKR, 2013).

Berdasarkan hasil Riset Kesehatan Dasar (Riskesdas) tahun 2013, terdapat 37,1\% ibu hamil yang anemia yaitu ibu hamil yang kadar $\mathrm{Hb}$ nya kurang dari 11,0 g/dl, dengan proporsi yang hampir sama di kawasan perkotaan $(36,4 \%)$ dan perdesaan $(37,8 \%)$ (Direktorat Bina Gizi KIA, 2011). Elhassan et al (2010) menyatakan, ibu hamil yang menderita anemia defisensi besi akan beresiko sembilan kali lebih besar untuk melahirkan BBLR. Anak yang lahir dengan BBLR akan cenderung mempunyai status gizi kurang yang salah satunya yaitu status gizi pendek atau stunting (Roscha B, 2017).

51 Edukasi Masyarakat Sehat Sejahtera (EMaSS) : Jurnal Pengabdian kepada Masyarakat Volume 2 No.1 Tahun 2020 
Di Provinsi Kalimantan Tengah jumlah anak stunting sampai akhir 2017 mencapai 39\% dari total anak balita. Kabupaten yang prevalensi stunting tinggi adalah Kabupaten Murung Raya, Gunung Mas dan Barito Timur. Kabupaten Barito Timur merupakan salah satu Kabupaten yang angka kejadian stunting tinggi yaitu sebesar 54,84\% (TNPPK, 2017).

Pemerintah Indonesia dalam upaya meningkatkan kesehatan ibu dan anak melalui program kelas ibu hamil. Kelas Ibu hamil merupakan kelompok belajar ibu-ibu hamil dengan umur kehamilan antara 20 minggu s/d 32 minggu dengan jumlah peserta maksimal 10 orang. Melalui kelas Ibu hamil, diharapkan dapat meningkatkan pengetahuan dan keterampilan ibu-ibu mengenai kehamilan, perawatan kehamilan, persalinan, perawatan nifas, perawatan bayi baru lahir, mitos, penyakit menular dan akte kelahiran (Kemenkes, 2015). Maka berdasarkan latar belakang di atas dilaksanakan pengabdian masyarakat “ Implementasi kelas ibu hamil sebagai upaya penurunan stunting di wilayah kerja Puskesmas Ampah II Kabupaten Barito Timur”.

\section{METODE}

Metode pelaksanaan kegiatan pengabdian masyarakat ini dengan pendidikan kesehatan melalui kelas ibu hamil. Pada kelas ibu hamil ini sasaran kegiatan adalah ibu hamil di wilayah kerja Puskesmas Ampah II. Mitra yang terlibat dalam kegiatan yaitu bidan, kader dan bidang kesehatan keluarga Dinas Kesehatan Kabupaten Barito Timur. Melalui, implementasi kegiatan ini untuk meningkatkan pengetahuan ibu hamil tentang pencegahan stunting.

Kegiatan dilaksanakan selama 2 hari dan bertempat di Poskesdes Ampah II. Kegiatan ini dilakukan melalui 3 tahapan yaitu tahap persiapan, tahap pelaksanaan dan tahap evaluasi. Pada tahap persiapan dimulai dari pengajuan permohonan ijin kegiatan ke Dinasi Kesehatan Kabupaten Barito Timur, koordinasi dengan Dinas Kesehatan Kabupaten Barito Timur, koordinasi dengan kepala Puskesmas dan bidan Bidan Puskesmas Ampah II Kabupaten Barito Timur. Selain itu pada tahap persiapan, tim pengabdian masyarakat melakukan pembuatan materi, alat bantu leaflet, booklet serta kuesioner. Pada tahap pelaksanaan kegiatan kelas ibu hamil dilakukan dengan pemberian pendidikan kesehatan menggunakan multimedia, video dan leaflet/booklet. Materi yang akan diberikan kepada ibu hamil tentang cara pencegahan stunting pada masa kehamilan. Selain pemberian materi, pada kelas ibu hamil juga dilakukan sharing pengalaman antara ibu hamil selama menjalani kehamilannya. Selanjutnya, tahap evaluasi kegiatan dilakukan sebelum 
dan sesudah pemberian materi tentang stunting dan anemia pada kehamilan. Instrumen tahap evaluasi dengan menggunakan kuesioner untuk mengetahui besar peningkatan pengetahuan pada ibu hamil.

\section{HASIL DAN PEMBAHASAN}

Pelaksanaan pengabdian masyarakat melalui kegiatan kelas ibu hamil dilaksanakan dengan dihadiri 8 orang ibu hamil, didampingi oleh 2 orang bidan Puskesmas Ampah II dan kader kesehatan. Kegiatan kelas ibu hamil berjalan dengan lancar, materi tersampaikan dengan baik dan ada proses interaksi, serta berbagi pengalaman dengan peserta. Melalui kegiatan kelas ibu hamil ini didapatkan informasi terkait pengalaman dan masalah maupun kebutuhan yang dialami ibu hamil selama menjalani proses kehamilannya. Bidan dan kader juga semakin mengenal lebih dekat ibu hamil di Poskesdes Ampah II.

Gambaran peningkatan pengetahuan pada ibu hamil tentang stunting dan anemia pada kehamilan dapat dilihat pada Tabel di bawah ini:

\section{Tabel 1. Gambaran Pengetahuan Ibu Hamil Sebelum Kelas Ibu Hamil (Pre test)}

\begin{tabular}{lcc}
\hline \multicolumn{1}{c}{ Kategori } & Jumlah & Persen (\%) \\
\hline Baik & 1 & 12,5 \\
Sedang & 5 & 62,5 \\
Kurang & 2 & 25 \\
\hline Jumlah & $\mathbf{8}$ & $\mathbf{1 0 0}$ \\
\hline
\end{tabular}

Berdasarkan Tabel 1. menunjukan bahwa sebagian besar pengetahuan ibu hamil sebelum diberikan materi pada kategori kurang sebesar 25\% dan kategori sedang sebesar 62,5\%. Ibu hamil yang memiliki pengetahuan baik hanya hanya 1 orang atau sebesar $12,5 \%$.

Selanjutnya, gambaran pengetahuan ibu hamil setelah diberikan materi tentang stunting pada kehamilan melalui kelas ibu hamil dapat dilihat pada Tabel 2 di bawah ini: 
Tabel 2. Gambaran Pengetahuan Ibu Hamil Setelah Kelas Ibu Hamil (Post test)

\begin{tabular}{lcc}
\hline \multicolumn{1}{c}{ Kategori } & Jumlah & Persen (\%) \\
\hline Baik & 6 & 75 \\
Sedang & 2 & 25 \\
Kurang & 0 & 0 \\
\hline Jumlah & $\mathbf{8}$ & $\mathbf{1 0 0}$ \\
\hline
\end{tabular}

Pada Tabel 2 di atas menunjukan bahwa setelah dilaksanakan kelas ibu hamil dengan pemberian materi pengetahuan ibu hamil mengalami peningkatan yaitu pada kategori baik sebesar $75 \%$ dan kategori sedang sebesar $25 \%$.

Berdasarkan Tabel 2. menunjukan bahwa kegiatan pengabdian masyarakat melalui kegiatan kelas ibu hamil dalam upaya penurunan stunting dapat meningkatkan pengetahuan dan pemahaman ibu hamil. Kegiatan peningkatan pengetahuan melalui kelas ibu hamil merupakan salah satu cara yang efektif karena, kelas Ibu Hamil merupakan sarana belajar kelompok bagi ibu hamil, dalam bentuk tatap muka, bertujuan meningkatkan pengetahuan dan keterampilan ibu-ibu mengenai kehamilan, persalinan, perawatan nifas, dan perawatan bayi baru lahir melalui praktek dengan menggunakan Buku KIA (Kemenkes, 2015). Hasil penelitian Oktaviani (2018) melaporkan bahwa melalui kelas ibu hamil tingkat kecemasan ibu hamil dalam menghadapi persalinan. Ibu hamil yang siap dalam menjalani kehamilan dan menghadapi persalinan akan menurunkan risiko komplikasi pada kehamilan dan persalinan.

Melalui pelaksanaan kegiatan kelas ibu hamil di wilayah kerja Puskesmas Ampah II, ibu hamil terdapat peningkatan pengetahuan tentang stunting dan ibu hamil dapat melakukan interaksi dan diskusi mengenai masalah maupun kebutuhan selama masa kehamilan. Kelas ibu hamil memang merupakan sarana untuk mendapatkan teman dan bertanya serta memperoleh informasi terkait kehamilan, persalinan dan masa nifas. Selain mendapatkan informasi tentang masalah dan kebutuhan ibu hamil, bidan di Puskesmas juga semakin mengenal lebih dekat ibu hamil. Sesuai dengan manfaat kelas ibu hamil supaya mendekatkan bidan dengan ibu hamil dan keluarga. 


\section{SIMPULAN}

Implementasi Kelas ibu hamil sebagai salah satu wahana yang dapat digunakan dalam berbagi informasi pengetahuan dan wawasan mengenai stunting. Ibu hamil di wilayah kerja Puskesmas Ampah II mendapatkan informasi pengetahuan dan wawasan mengenai stunting.

\section{DAFTAR PUSTAKA}

Dinkes Provinsi Kalteng.(2016). Profil Kesehatan Provinsi Kalimantan Tengah Tahun 2017.

Direktorat Bina Gizi dan KIA.(2011). Program Penanggulangan Stunting. Kemenkes : Jakarta

Elhassan, M.E., Abbaker, A. O., Haggaz, A. D., Abubaker, M. S., Adam, I. (2010). Anemia and Low Birth Weight in Medani, Hospital Sudan. BMC.

Kementerian Desa Pembangunan Daerah Tertinggal dan Transmigrasi.(2017). Buku Saku Desa Dalam Penanganan Stunting. KDPDTT : Jakarta

Kementerian Kesehatan RI. (2013). Laporan Nasional Riskesdas 2013. Badan Penelitian dan Pengembangan Kesehatan.

Kementerian Kesehatan RI. (2015). Modul Pelatihan bagi pelatih fasilitator kelas Ibu. Direktorat Jendral Bina Gizi dan kesehatan Ibu dan Anak. Jakarta

Kementerian Koordinator Bidang Kesejahteraan Rakyat.(2013). Kerangka Kebijakan Gerakan Nasional Percepatan Gizi Dalam Rangka Seribu Hari Pertama Kehidupan (Gerakan 1000 HPK). RI. Jakarta

Oktaviani. (2018). The Efficiency Of Conducting Pregnancy Session Toward Reducing The Level Of Anxiety To Delover Baby. Indian Journal of Public Health Research \& Development Vol $9(10)$.

Rosha Ch Bunga, Hardiansyah, Yayuk Farida Baliwati. (2012). Analisis Determinan stunting Anak 023 bulan pada daerah miskin di Jawa Tengah dan Jawa Timur. Jurnal Penelitian Gizi

Tim Nasional Percepatan Penanggulangan Kemiskinan. (2017). 100 Kabupaten/Kota Prioritas Untuk Intervensi Anak Kerdil (Stunting). Jakarta 